\title{
Pyrrolo[1,2-b][1,2,5]benzothiadiazepines (PBTDs): A New Class of Agents with High Apoptotic Activity in Chronic Myelogenous Leukemia K562 Cells and in Cells from Patients at Onset and Who Were Imatinib-Resistant
}

Romano Silvestri,,$\dagger$ Gabriella Marfè, ${ }^{\dagger}$ Marino Artico,${ }^{\dagger}$ Giuseppe La Regina,${ }^{\dagger}$ Antonio Lavecchia, ${ }^{\S}$ Ettore Novellino,$\S$ Manuela Morgante, ${ }^{\#}$ Carla Di Stefano, ${ }^{\ddagger}$ Gianfranco Catalano, ${ }^{\|}$Giuseppe Filomeni, ${ }^{\perp}$ Elisabetta Abruzzese," Maria Rosa Ciriolo, ${ }^{\perp}$ Matteo Antonio Russo, ${ }^{\#}$ Sergio Amadori," Roberto Cirilli, ${ }^{\infty}$ Francesco La Torre, ${ }^{\infty}$ and Paola Sinibaldi Salimei ${ }^{\ddagger}$

Istituto Pasteur-Fondazione Cenci Bolognetti, Dipartimento di Studi Farmaceutici, Università "La Sapienza”, Piazzale Aldo Moro 5, I-00185 Roma, Italy, Dipartimento di Medicina Sperimentale e Scienze Biochimiche, Università "Tor Vergata”, Via Montpellier 1, I-00133 Roma, Italy, Dipartimento di Chimica Farmaceutica e Tossicologica, Università di Napoli "Federico II", Via Domenico Montesano 49, I-80131 Napoli, Italy, Dipartimento di Medicina Sperimentale e Patologia, Università "La Sapienza”, Viale Regina Elena 324, I-00161 Roma, Italy, Cattedra di Ematologia, Università "Tor Vergata", Ospedale "Sant'Eugenio", Piazzale dell'Umanesimo 10, I-00144 Roma, Italy, Dipartimento di Biologia, Università "Tor Vergata”, Via della Ricerca Scientifica, I-00133 Roma, Italy, and Dipartimento del Farmaco, Istituto Superiore di Sanità, Viale Regina Elena 299, I-00161 Roma, Italy

Received March 10, 2006

Pyrrolo[1,2-b][1,2,5]benzothiadiazepine 5,5-dioxides (PBTDs) induced apoptosis in human BCR-ABLexpressing leukemia cells. The apoptotic activity was also observed in primary leukemic blasts, obtained from chronic myelogenous leukemia (CML) patients at onset or from patients in blast crisis and who were imatinib-resistant. Compounds $\mathbf{5}$ and $\mathbf{1 4}$ induced apoptosis before BCR-ABL protein expression and tyrosin phosphorylation were affected and activated different caspases in the apoptotic pathway. PBTDs are a new class of valid candidates for the treatment of CML.

Chronic myelogenous leukemia (CML) is a clonal disease of hemopoietic progenitor cells. ${ }^{1} \mathrm{CML}$ is characterized by the expression of the BCR-ABL fusion gene, which is derived from the fusion of the cellular breakpoint cluster region (BCR) gene and the Abelson murine leukemia oncogene (ABL). ${ }^{2} \mathrm{BCR}-\mathrm{ABL}-$ transformed cells activate multiple signal transduction pathways responsible for increasing proliferation. The BCR-ABL protein also activates downstream survival pathways ${ }^{3}$ that collectively provide BCR-ABL cells with a survival advantage over the normal cells, thereby contributing to the leukemic phenotype ${ }^{4}$ and conferring higher resistance against conventional cytotoxic drugs. $^{5}$

Imatinib (IM, imatinib mesilate, STI-571, Gleevec) (1) is now the first-choice drug for all newly diagnosed CML patients ${ }^{6}$ (Chart 1). IM is a potent inhibitor in all of the ABL tyrosine kinases, including BCR-ABL. There is a lot of evidence that the oncogene BCR-ABL would protect growth-factor-dependent hemopoietic cells from apoptosis. According to this role, inhibition of BCR-ABL expression by IM showed restoration of susceptibility to apoptosis and enhancement of cell death. ${ }^{7}$ Exposure to IM alone induced apoptosis in HL-60/BCR-ABL and K562 cells. ${ }^{8}$ Despite its initial efficacy, IM selects drug resistance due to the emergence of mutation at the kinase domain

* To whom correspondence should be addressed. Phone: +3906 4991 3800. Fax: +3906 491 491. E-mail: romano.silvestri@uniroma1.it.

† Dipartimento di Studi Farmaceutici, Università "La Sapienza".

Dipartimento di Medicina Sperimentale e Scienze Biochimiche, Università "Tor Vergata"

§ Università di Napoli "Federico II".

\# Dipartimento di Medicina Sperimentale e Patologia, Università "La Sapienza".

"Cattedra di Ematologia, Università "Tor Vergata".

$\perp$ Dipartimento di Biologia, Università "Tor Vergata".

${ }^{\infty}$ Dipartimento del Farmaco, Istituto Superiore di Sanità.
Chart 1

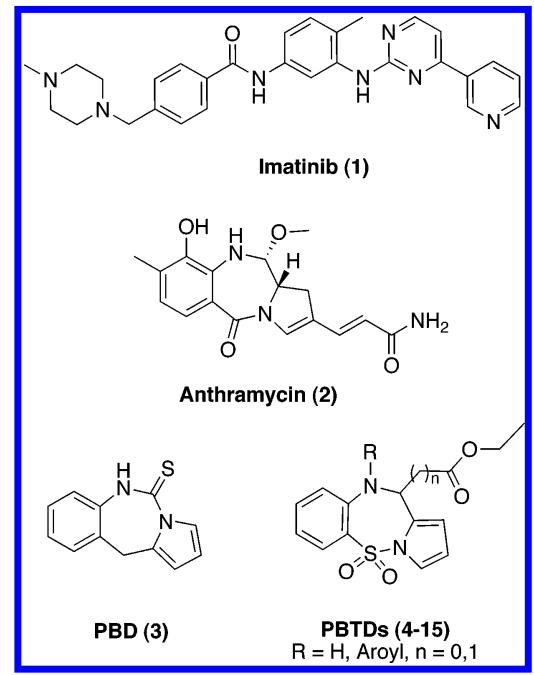

and overexpression of BCR-ABL. ${ }^{9}$ To overcome resistance, some strategies have been adopted, such as dose escalation and synergistic combination with conventional drugs (cytarabine, homoharringtonine, IFN), alternative ABL inhibitors, or BCRABL protein down-regulating agents. ${ }^{7}$

The antitumor activity of pyrrolo[2,1-c][1,4]benzodiazepines (PBDs) related to anthramycin (2) was extensively studied by our research group, as it is well documented in Thurston's excellent review. ${ }^{10} \mathrm{~A}$ correlation between antitumor activity and apoptosis was well demonstrated. It was hypothesized that anthramycin, like other DNA-alkylating agents, would induce apoptosis through a mythocondrial pathway. ${ }^{11}$ In addition, in 
Table 1. Apoptotic Activity of Compounds 4-18 and Reference Compound $\mathbf{1}$ in K562 Cells at $10 \mu \mathrm{M}^{a}$

\begin{tabular}{|c|c|c|c|c|}
\hline \multirow[b]{2}{*}{ compd } & \multicolumn{4}{|c|}{$\%$ of apoptosis $( \pm \mathrm{SD})^{b}$} \\
\hline & $8 \mathrm{~h}$ & $16 \mathrm{~h}$ & $24 \mathrm{~h}$ & $48 \mathrm{~h}$ \\
\hline 4 & $45.0 \pm 2.0$ & $66.6 \pm 1.5$ & $80.0 \pm 1.0$ & $89.6 \pm 0.6$ \\
\hline 5 & $45.6 \pm 1.5$ & $67.6 \pm 1.5$ & $79.6 \pm 1.5$ & $91.7 \pm 0.6$ \\
\hline 6 & $44.3 \pm 1.5$ & $67.0 \pm 2.0$ & $79.7 \pm 1.5$ & $91.7 \pm 0.6$ \\
\hline 7 & $45.3 \pm 2.1$ & $67.6 \pm 1.5$ & $81.0 \pm 1.0$ & $92.0 \pm 1.0$ \\
\hline 8 & $43.7 \pm 1.7$ & $66.0 \pm 1.0$ & $77.0 \pm 1.0$ & $87.6 \pm 1.1$ \\
\hline 9 & $45.3 \pm 1.1$ & $68.0 \pm 1.0$ & $79.5 \pm 2.5$ & $92.3 \pm 2.1$ \\
\hline 10 & $45.0 \pm 2.6$ & $67.6 \pm 2.1$ & $74.3 \pm 2.5$ & $87.6 \pm 1.5$ \\
\hline 11 & $43.0 \pm 2.6$ & $65.5 \pm 2.1$ & $78.0 \pm 1.0$ & $90.0 \pm 3.6$ \\
\hline 12 & $44.6 \pm 1.5$ & $66.3 \pm 1.5$ & $79.0 \pm 2.0$ & $90.7 \pm 1.7$ \\
\hline 13 & $47.0 \pm 2.0$ & $69.0 \pm 1.0$ & $80.0 \pm 0.0$ & $92.6 \pm 3.0$ \\
\hline 14 & $34.0 \pm 1.7$ & $61.3 \pm 0.6$ & $76.3 \pm 1.1$ & $89.7 \pm 2.1$ \\
\hline 15 & $29.3 \pm 0.6$ & $53.0 \pm 1.0$ & $72.0 \pm 2.6$ & $88.3 \pm 0.6$ \\
\hline 16 & $4.8 \pm 0.6$ & $5.7 \pm 1.5$ & $6.8 \pm 1.5$ & $6.2 \pm 2.1$ \\
\hline 17 & $4.5 \pm 0.6$ & $5.5 \pm 1.5$ & $6.4 \pm 1.5$ & $6.1 \pm 2.1$ \\
\hline 18 & $5.3 \pm 1.5$ & $19.3 \pm 1.5$ & $19.6 \pm 0.6$ & $23.0 \pm 1.7$ \\
\hline $\mathbf{1}^{c}$ & $66.7 \pm 1.5$ & $70.0 \pm 1.0$ & $71.0 \pm 1.5$ & $71.2 \pm 2.1$ \\
\hline control $^{d}$ & $4.4 \pm 0.6$ & $5.3 \pm 1.5$ & $6.4 \pm 1.5$ & $6.1 \pm 1.2$ \\
\hline
\end{tabular}

${ }^{a}$ Compounds 4-18 were tested in parallel with the reference compound 1 as described in Supporting Information. ${ }^{b}$ Arithmetic mean \pm standard deviation (SD) for triplicate experiments. ${ }^{c}$ Imatinib, Gleevec. ${ }^{d}$ Untreated K562 cells.

Table 2. Apoptotic Activity of Compounds 5 and $\mathbf{1 4}$ in Cells from CML Patients at Onset at $10 \mu \mathrm{M}$

\begin{tabular}{|c|c|c|c|c|c|c|c|}
\hline \multirow[b]{3}{*}{ patient } & \multirow[b]{3}{*}{ sex } & \multirow[b]{3}{*}{ age (years) } & \multirow[b]{3}{*}{ source ${ }^{a}$} & \multicolumn{4}{|c|}{$\%$ of apoptosis } \\
\hline & & & & \multicolumn{2}{|c|}{5} & \multicolumn{2}{|c|}{14} \\
\hline & & & & $24 \mathrm{~h}$ & $48 \mathrm{~h}$ & $24 \mathrm{~h}$ & $48 \mathrm{~h}$ \\
\hline 1 & $\mathrm{M}$ & 45 & PB & 77 & 85 & 64 & 70 \\
\hline 2 & $\mathrm{M}$ & 60 & $\mathrm{BM}$ & 70 & 85 & 50 & 70 \\
\hline 3 & $\mathrm{~F}$ & 73 & PB & 66 & 82 & 65 & 79 \\
\hline 4 & $\mathrm{M}$ & 83 & $\mathrm{BM}$ & 50 & 75 & 50 & 70 \\
\hline 5 & $\mathrm{~F}$ & 46 & PB & 60 & 80 & 50 & 70 \\
\hline 6 & F & 27 & PB & 60 & 80 & 50 & 70 \\
\hline 7 & $\mathrm{~F}$ & 45 & PB & 64 & 80 & 60 & 80 \\
\hline 8 & M & 35 & PB & 65 & 85 & 60 & 80 \\
\hline 9 & M & 66 & PB & 60 & 80 & 60 & 80 \\
\hline 10 & $\mathrm{~F}$ & 38 & PB & 70 & 80 & 50 & 70 \\
\hline 11 & $\mathrm{~F}$ & 65 & PB & 55 & 78 & 52 & 71 \\
\hline 12 & $\mathrm{~F}$ & 27 & PB & 55 & 78 & 52 & 73 \\
\hline
\end{tabular}

${ }^{a} \mathrm{~PB}$ : peripheral blood cells. BM: bone marrow cells.

the past few years the activity of some PBDs (i.e., 3$)^{12}$ in leukemia cell lines, such as K562 and Jurkat cells, was reported.

Our extensive studies on anti-AIDS agents led to the discovery of pyrrolo[1,2- $b][1,2,5]$ benzothiadiazepine 5,5dioxides (PBTDs) as potent non-nucleoside inhibitors of the HIV-1 reverse transcriptase. ${ }^{13}$ Given the high structural similarity between PBTDs and PBDs, we selected two PBTDs ( $\mathbf{5}$ and 14) for a preliminary screening aimed to discover new proapoptotic and antileukemia agents. In fact, to our knowledge the anti-CML properties of PBTDs have not been investigated until now.

In our first experiments, PBTDs $\mathbf{5}$ and $\mathbf{1 4}$ induced apoptosis in K562 cells (Table 1). In addition, they efficiently induced cell death in BCR-ABL-positive leukemia cells taken from patients who were at onset or were IM-resistant (Tables 2 and 3 ). These results prompted us to conduct apoptotic mechanism studies on PBTDs $\mathbf{5}$ and $\mathbf{1 4}$. At the same time we planned the synthesis of new PBTD derivatives to investigate the effect of (i) substituents at the 10-aroyl group, (ii) a 1-naphthoyl group at position 10, and (iii) the introduction of a methylene spacer group at position 11. Our findings indicate that the PBTDs are a new class of potential agents for the treatment of CML.
Table 3. Apoptotic Activity of Compounds $\mathbf{5}$ and $\mathbf{1 4}$ at $10 \mu \mathrm{M}$ in Cells from CML Patients in Blast Crisis and Who Were Imatinib-Resistant

\begin{tabular}{|c|c|c|c|c|c|c|c|}
\hline \multirow[b]{3}{*}{ patient } & \multirow[b]{3}{*}{ sex } & \multirow[b]{3}{*}{ age } & \multirow[b]{3}{*}{ source $^{a}$} & \multicolumn{4}{|c|}{$\%$ of apoptosis } \\
\hline & & & & \multicolumn{2}{|c|}{5} & \multicolumn{2}{|c|}{14} \\
\hline & & & & $24 \mathrm{~h}$ & $48 \mathrm{~h}$ & $24 \mathrm{~h}$ & $48 \mathrm{~h}$ \\
\hline 13 & $\mathrm{M}$ & 38 & PB & 60 & 80 & 40 & 60 \\
\hline 14 & $\mathrm{~F}$ & 70 & PB & 55 & 78 & 50 & 70 \\
\hline
\end{tabular}

${ }^{a} \mathrm{~PB}$ : peripheral blood cells.

\section{Scheme $1^{a}$}

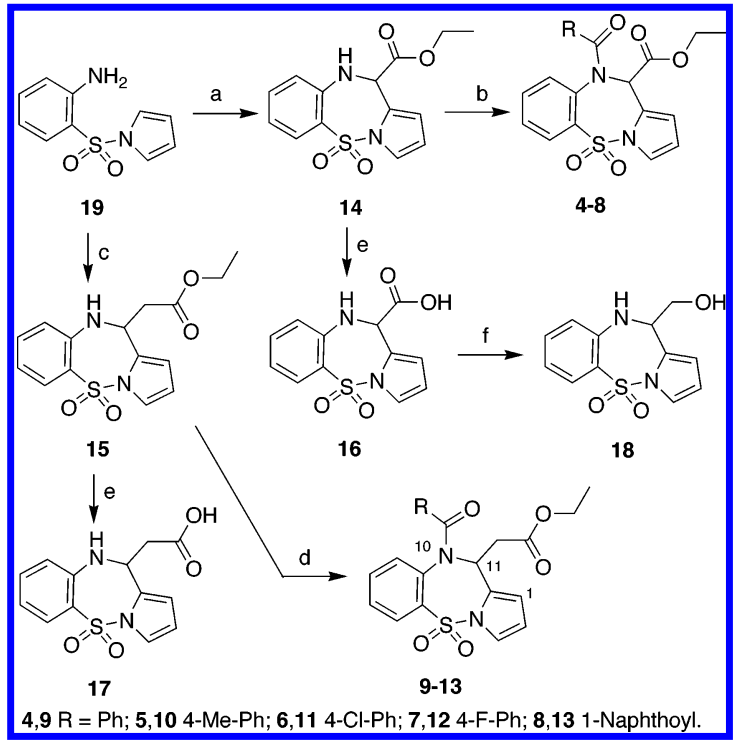

${ }^{a}$ Reagents and reaction conditions: (a) ethyl glyoxylate dimethoxyacetal, PTSA, absolute EtOH, reflux, overnight; (b) aroyl chloride, $\mathrm{NaHCO}_{3}$, 1-bromo-3-chloropropane, reflux, overnight; (c) ethyl 3,3-diethoxy-propionate, $\mathrm{CH}_{3} \mathrm{COOH} \cdot \mathrm{H}_{2} \mathrm{O}$, overnight; (d) aroyl chloride, $(i-\mathrm{Bu})_{3} \mathrm{~N}$, dry dioxane, reflux, $48 \mathrm{~h}$; (e) $\mathrm{LiOH}, \mathrm{THF} \cdot \mathrm{H}_{2} \mathrm{O}$, room temp, $24 \mathrm{~h}$; (f) $\mathrm{LiAlH}_{4}, \mathrm{AlCl}_{3}$, anhydrous THF, room temp, $3 \mathrm{~h}$.

\section{Chemistry}

Aroylation of the ester $\mathbf{1 4}$ with aroyl chlorides in boiling 1-bromo-3-chloropropane in the presence of sodium hydrogen carbonate afforded the corresponding amides 4-8 (Scheme 1). The starting ester 14 was prepared by treatment of $19^{14}$ with ethyl 2,2-diethoxyacetate in the presence of 4-toluenesulfonic acid (PTSA) as a catalyst in boiling absolute ethanol via a Pictet-Spengler type reaction. ${ }^{15}$ Derivatives 9-13 were prepared by aroylation of $\mathbf{1 5}$ in boiling dioxane in the presence of triisobutylamine. The starting acetate $\mathbf{1 5}$ was obtained by reaction of 19 with ethyl 3,3-diethoxypropionate in aqueous glacial acetic acid at $100{ }^{\circ} \mathrm{C}$. Lithium hydroxide hydrolysis of the esters $\mathbf{1 4}$ and $\mathbf{1 5}$ afforded the corresponding acids $\mathbf{1 6}$ and 17. Lithium aluminum hydride-aluminum chloride reduction of acid $\mathbf{1 4}$ gave alcohol 18. The racemic mixtures 5 and $\mathbf{1 4}$ were separated using analytical and semipreparative enantioselective HPLC to give enantiomers $\mathbf{2 0}$ and $\mathbf{2 1}$, and $\mathbf{2 2}$ and $\mathbf{2 3}$, respectively, with $>98.0 \%$ ee and in $80-90 \%$ yield.

\section{Apoptotic Activity in K562 Cells}

The characteristic morphological features of apoptosis, such as cytoplasmic vacuolization, patterns of chromatin condensation and micronuclei, and negligible necrosis, were observed upon treatment of the cells with tested compounds. The chromatin appeared clumped and was observed at the nuclear periphery. The samples showed micronuclei or the nuclear body surrounded by a double membrane and cytoplasmic vacuolization. Large plasmalemmal blebbing was visible in the cells incubated with 


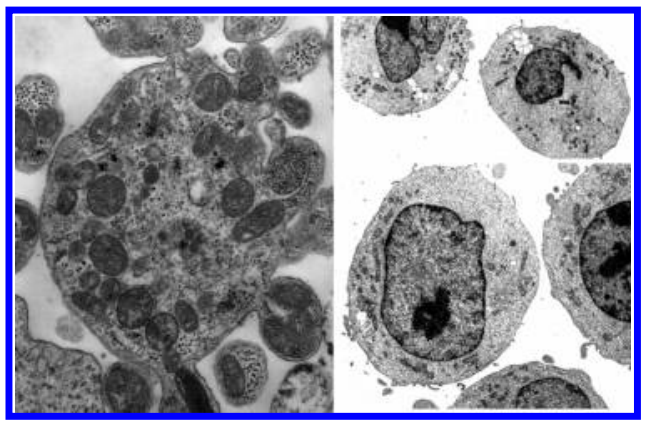

Figure 1.

5 (Figure 1, left $(\times 18000))$, whereas such morphological changes did not appear in the control cells (Figure 1, right).

The apoptotic activity of $\mathbf{5}$ and $\mathbf{1 4}$ in K562 cells was timedependent at 5, 10, and $15 \mu \mathrm{M}$ (Figure $1 \mathrm{~S}$ in Supporting Information). At $10 \mu \mathrm{M}, \mathbf{4 - 1 5}$ showed high apoptotic activity at every time point. A preliminary structure-activity relationship (SAR) inspection indicated that the apoptotic activity of 4-13 was weakly affected by the aroyl substitutents at position 10 of the PBTD nucleus or by the methylene linker at position 11 (compare carboxylates $\mathbf{4 - 8}$ and acetates 9-13). Compounds 14 and 15 deprived of the 10-aroyl portion also showed potent apoptotic activity with greater difference after $8 \mathrm{~h}$ (compare 4-13 with 14 and 15). Replacement of the ester 14 with the alcohol 18 caused a neat decrease of apoptotic activity. Free acids $\mathbf{1 6}$ and $\mathbf{1 7}$ did not show the morphological features of apoptosis, showing an apoptotic activity that was comparable to that of control cells. We hypothesized that these compounds would not be able to penetrate the K562 cell membrane and to activate the cellular mechanisms. To evaluate the influence of the chiral center at position 11 of the PBTD ring, the racemates 5 and 14 were separated by chiral HPLC. Both $(+)-(S)-$ enantiomers 21 and $\mathbf{2 3}$ and the corresponding (-)-(R)counterparts 22 and $\mathbf{2 4}$ showed slight differences of activity in the range 3-5\% (Table 1S in Supporting Information).

\section{Apoptotic Activity in Bone Marrow and Peripheral Blood Cells from CML Patients}

We harvested bone marrow and peripheral blood cells from 12 consecutive CML patients at onset. We also harvested peripheral blood cells from 2 patients in blast crisis evolved under IM treatment. Cell samples were cultured in vitro, treated with 5 or 14 for 24 and $48 \mathrm{~h}$, and then subjected to DNA fragmentation assay. Tested PBTDs induced apoptosis in all of the samples, including those from the two patients in blast crisis and who were IM-resistant (Tables 2 and 3). The typical appareance of endonucleosome DNA after treatment with 5, 6, or $\mathbf{1 4}$ in patients cases 1,11 , and 14 is shown in Figure $2 \mathrm{~S}$ in Supporting Information.

\section{Caspase Activation Activity in K562 Cells}

We analyzed the activated apoptotic pathways by performing Western blot analyses of caspase-8 and -9 proforms. Upon drug treatment caspase- 8 and -9 became activated in most apoptotic models in receptor-activated caspase- 8 and -3 pathways or in cytochrome c release-dependent caspase- 9 and -3 pathways.

In both pathways, caspase- 3 activation is the final event of the caspase cascade. After 24 h, 14 significantly reduced the procaspase- 8 immunoreactive band without changing the procaspase-9 intensity. On the other hand, lysates from 5-treated K562 cells showed no evidence of alteration in procaspase- 8 concentration and paralleled a dramatic decrease of procaspase- 9 expression levels. Compound $\mathbf{1 4}$ seemed to activate the direct extrinsic caspase-8 mediated pathway, resulting in faster proteolysis induction.

In contrast, 5 seemed to induce apoptosis through the mitochondrial intrinsic pathway with a relatively delayed proteolytic effect (Figure 3S in Supporting Information).

\section{Compounds 5 and 14 Induced Apoptosis by Bypassing the Apoptotic Suppressor BCR-ABL}

Western blot analyses of BCR-ABL and tyrosine phosphorylated proteins at different intervals showed that some downregulation of the BCR-ABL immunoreactive band was detected only after $16 \mathrm{~h}$ upon treatment with 14 and after $24 \mathrm{~h}$ upon treatment with $\mathbf{5}$. One point worth noting was that at regular intervals we noticed a slight diminution of $\mathrm{ABL}$ and actin proteins. At the same time, no significant early change in the pattern of tyrosine phosphorylated proteins was detected (at least not until the same BCR-ABL protein level started to fade). This confirmed that no inhibition of a putative BCR-ABL-mediated major phosphorylative process was induced within the cell. These observations suggested that down-regulation of BCRABL is not involved in the early events associated with PTDBinduced apoptosis. Accordingly, both $\mathbf{5}$ and $\mathbf{1 4}$ induced apoptosis before the levels of BCR-ABL protein expression and its tyrosin phosphorylation were affected. Both actin protein degradation and whole-cell phosphorylation pattern changes (caused by widespread proteolysis) were dependent on the apoptotic process rather than the inactivation of BCR-ABL kinase (Figure $4 \mathrm{~S}$ in Supporting Information).

In conclusion, our preliminary results demonstrated that PBTDs 4-15 induced apoptosis in human BCR-ABL-expressing leukemia cells. The apoptotic activity was also observed in primary leukemia blasts, obtained from CML patients at onset or from patients in blast crisis and who were IM-resistant. Apoptotic mechanism studies conducted on PBTDs 5 and $\mathbf{1 4}$ showed that they activated the caspase activity through two different pathways. These compounds also induced apoptosis before the BCR-ABL protein expression and tyrosine phosphorylation levels were affected. These findings suggest that PBTDs are endowed with powerful growth inhibition on leukemia cells.

Besides the high activity displayed by some PBTDs discovered in the present preliminary work, we are aware that further results are obtainable to evaluate the chemotherapeutic potential of this novel class of anti-CML agents. For this reason, the synthesis of new PBTD derivatives is now ongoing in our laboratories as part of more in-depth structure-activity relationship (SAR) studies guided by molecular modeling.

\section{Experimental Section}

Chemistry. Melting points (mp) were determined on a Büchi 510 apparatus and are uncorrected. Infrared spectra (IR) were run on a SpectrumOne FT spectrophotometer. Band position and absorption ranges are given in $\mathrm{cm}^{-1}$. Proton nuclear magnetic resonance $\left({ }^{1} \mathrm{H}\right.$ NMR) spectra were recorded on Bruker 200 and $400 \mathrm{MHz}$ FT spectrometers in the indicated solvent. Chemical shifts are expressed in $\delta$ units (ppm) from tetramethylsilane. Column chromatography was performed on columns packed with alumina from Merck (70-230 mesh) or with silica gel from Merck (70230 mesh). Aluminum oxide TLC cards from Fluka (aluminum oxide precoated aluminum cards with fluorescent indicator at 254 $\mathrm{nm}$ ) and silica gel TLC cards from Fluka (silica gel precoated aluminum cards with fluorescent indicator at $254 \mathrm{~nm}$ ) were used for thin-layer chromatography (TLC). Elemental analysis results were found within $\pm 0.4 \%$ of the theoretical values. 
General Procedure for the Prepapartion of Derivatives 4-8. Example. Ethyl ( \pm )-10,11-Dihydro-10-benzoylpyrrolo[1,2-b]$[1,2,5]$ benzothiadiazepine-11-carboxylate 5,5-Dioxide (4). A mixture of 14 ( $1.00 \mathrm{~g}, 0.0033 \mathrm{~mol})$, benzoyl chloride $(0.48 \mathrm{~g}, 0.0034$ $\mathrm{mol}), \mathrm{NaHCO}_{3}(0.31 \mathrm{~g}, 0.0037 \mathrm{~mol})$, and 1-bromo-3-chloropropane $(50 \mathrm{~mL})$ was refluxed overnight. After cooling, the mixture was filtered and the solvent evaporated. The residue was purified by column chromatography (silica gel, chloroform). Yield 40\%, mp $172-180{ }^{\circ} \mathrm{C}$ (ethanol). ${ }^{1} \mathrm{H}$ NMR (DMSO- $\left.d_{6}\right): \delta 1.30(\mathrm{t}, J=7.0$ $\mathrm{Hz}, 3 \mathrm{H}), 4.28(\mathrm{~m}, 1 \mathrm{H}), 4.44(\mathrm{~m}, 1 \mathrm{H}), 6.16(\mathrm{~m}, 1 \mathrm{H}), 6.28(\mathrm{br}, 1 \mathrm{H})$, $6.34(\mathrm{~m}, 1 \mathrm{H}), 7.06(\mathrm{~d}, J=6.9 \mathrm{~Hz}, 1 \mathrm{H}), 7.25-7.51(\mathrm{~m}, 8 \mathrm{H}), 7.91$ ppm (dd, $J=1.5$ and $7.4 \mathrm{~Hz}, 1 \mathrm{H})$. IR (neat): $v 1185,1650,1745$ $\mathrm{cm}^{-1}$. Anal. $\left(\mathrm{C}_{21} \mathrm{H}_{18} \mathrm{~N}_{2} \mathrm{O}_{5} \mathrm{~S}\right.$ (410.44)), C, H, N, S.

General Procedure for the Prepapartion of Derivatives 9-13. Ethyl ( \pm )-10,11-Dihydro-10-benzoylpyrrolo[1,2- $b][1,2,5]$ benzothiadiazepine-11-acetate 5,5-Dioxide (9). A mixture of $\mathbf{1 5}(1.00$ $\mathrm{g}, 0.0031 \mathrm{~mol})$, benzoyl chloride $(0.56 \mathrm{~g}, 0.0040 \mathrm{~mol})$, triisobutylamine $(0.74,0.0040 \mathrm{~mol})$, and dry dioxane $(50 \mathrm{~mL})$ was refluxed for $48 \mathrm{~h}$. After concentration the mixture was extracted with ethyl acetate, washed with $1 \mathrm{~N} \mathrm{HCl}$ and then with brine, and dried. Removal of the solvent furnished a residue that was purified by column choromatography (silica gel, dichloromethane). Yield 35\%, mp $178-181{ }^{\circ} \mathrm{C}$ (ethanol). ${ }^{1} \mathrm{H}$ NMR (DMSO- $\left.d_{6}\right): \delta 1.19(\mathrm{t}, J=$ $7.1 \mathrm{~Hz}, 3 \mathrm{H}), 2.81(\mathrm{~m}, 1 \mathrm{H}), 2.91(\mathrm{~m}, 1 \mathrm{H}), 4.12(\mathrm{~m}, 2 \mathrm{H}), 6.35-6,40$ (m, 2H), 6.56 (br, 1H), 7.22-7.58 (m, 9H), $8.00 \mathrm{ppm}(\mathrm{m}, 1 \mathrm{H})$. IR (neat): $v 1186,1315,1655,1725 \mathrm{~cm}^{-1}$. Anal. $\left(\mathrm{C}_{22} \mathrm{H}_{20} \mathrm{~N}_{2} \mathrm{O}_{5} \mathrm{~S}\right.$ (424.47)), C, H, N, S.

Ethyl $( \pm)$-10,11-Dihydropyrrolo[1,2- $b][1,2,5]$ benzothiadiazepine -11-carboxylate 5,5-Dioxide (14). A mixture of 19 (9.4 g, $0.042 \mathrm{~mol})$, dimethoxyacetal of ethyl glyoxylate $(11.10 \mathrm{~g}, 0.063$ $\mathrm{mol}$ ), and 4-toluenesulfonic acid monohydrate (PTSA) (8.0 g, 0.042 mol) was refluxed in absolute ethanol $(20 \mathrm{~mL})$ overnight. PTSA (3.7 g, $0.021 \mathrm{~mol}$ ) was added while refluxing for an additional $4 \mathrm{~h}$. After cooling, the mixture was poured onto crushed ice and extracted with ethyl acetate, washed with brine, and dried. Evaporation of the solvent furnished the crude product, which was purified by column chromatography (silica gel, chloroform). Yield 51\%, $\mathrm{mp} 131-134{ }^{\circ} \mathrm{C}$ (toluene/ligroin) (lit. ${ }^{16 \mathrm{a}} \mathrm{mp} 121-122^{\circ} \mathrm{C}$ ).

Ethyl $( \pm)$-10,11-Dihydropyrrolo[1,2-b][1,2,5]benzothiadiazepine-11-acetate 5,5-Dioxide (15). 15 was prepared as 14 using ethyl 3,3-diethoxypropionate by heating in aqueous acetic acid. Yield $45 \%, \mathrm{mp} 121^{\circ} \mathrm{C}$ (from benzene/petroleum ether) (lit. ${ }^{16 \mathrm{~b}} \mathrm{mp} 118-$ $\left.119{ }^{\circ} \mathrm{C}\right)$.

$( \pm)-10,11-D i h y d r o p y r r o l o[1,2-b][1,2,5]$ benzothiadiazepine-11carboxylic Acid 5,5-Dioxide (16). Lithium hydroxide monohydrate $(0.25 \mathrm{~g}, 0.006 \mathrm{~mol})$ was added to a solution of $\mathbf{1 4}(0.61 \mathrm{~g}, 0.002$ $\mathrm{mol})$ in THF $(20 \mathrm{~mL})$ and water $(20 \mathrm{~mL})$. Then the reaction mixture was stirred at room temperature for $24 \mathrm{~h}$. After dilution with water, the mixture was acidified with $1 \mathrm{~N} \mathrm{HCl}$ until $\mathrm{pH} 2$ was reached. The acid was extracted with ethyl acetate, washed with brine, and dried. Removal of the solvent gave pure 16. Yield 98\%, mp 161$163{ }^{\circ} \mathrm{C}$ (aqueous ethanol) (lit. ${ }^{16 \mathrm{c}} \mathrm{mp} 159-162{ }^{\circ} \mathrm{C}$ ).

$( \pm)$-10,11-Dihydropyrrolo[1,2- $b][1,2,5]$ benzothiadiazepine-11acetic Acid 5,5-Dioxide (17). 17 was prepared as 16 starting from 15. Yield $90 \%, \mathrm{mp} 208-210{ }^{\circ} \mathrm{C}$ (ethanol) (lit. ${ }^{16 \mathrm{~b}} \mathrm{mp} 209{ }^{\circ} \mathrm{C}$ ).

$( \pm)-10,11-D i h y d r o-11-h y d r o x y m e t h y l p y r r o l o[1,2-b][1,2,5]-$ benzothiadiazepine 5,5-Dioxide (18). To anhydrous aluminum chloride $(0.71 \mathrm{~g}, 0.005 \mathrm{~mol})$ in THF $(30 \mathrm{~mL})$ at $0{ }^{\circ} \mathrm{C}$ was added lithium aluminum hydride $(8.0 \mathrm{~mL}$ of $1 \mathrm{M}$ in THF) while stirring for $15 \mathrm{~min}$. Then a solution of $\mathbf{1 6}(0.25 \mathrm{~g}, 0.00092 \mathrm{~mol})$ in THF $(10 \mathrm{~mL})$ was added and the mixture was stirred at room temperature for $3 \mathrm{~h}$. After cooling at $0{ }^{\circ} \mathrm{C}$, the reaction mixture was quenched with $4 \mathrm{~N}$ sodium hydroxide and extracted with dichloromethane. The organic layer was separated, washed with brine, and dried. Removal of the solvent gave crude 19, which was passed through a chromatographic column (silica gel, chloroform). Yield 87\%, mp $136-138{ }^{\circ} \mathrm{C}$ (ethanol) (lit. ${ }^{13} \mathrm{mp} 135-136{ }^{\circ} \mathrm{C}$ ).

Supporting Information Available: Additional chemical and biological information. This material is available free of charge via the Internet at http://pubs.acs.org.

\section{References}

(1) Faderl, S.; Talpaz, M.; Estrov, Z.; O’Brien, S.; Kurzrock, R.; Kantarjian, H. M. The biology of chronic myeloid leukemia. $\underline{\text { New }}$ Engl. J. Med. 1999, 341, 164-172.

(2) (a) Faderl, S.; Talpaz, M.; Estrov, Z.; Kantarjian, H. M. Chronic myelogenous leukemia: biology and therapy. Ann. Intern. Med. 1999, 131, 207-219. (b) Warmuth, M.; Danhauser-Riedl, S.; Hallek, M. Molecular pathogenesis of chronic myeloid leukemia: implications for new therapeutic strategies. Ann. Hematol. 1999, 78, 49-64.

(3) (a) Wang, J. Y. J. Integrative Signaling through Abl: A Tyrosine Kinase with Nuclear and Cytoplasmic Functions; Humana Press: Totowa, NJ, 2000; pp 303-324. (b) Voss, J.; Posern, G.; Hannemann, J. R.; Wiedemann, L. M.; Turhan, A. G.; Poirel, H.; Bernard, O. A.; Adermann, K.; Kardinal, C.; Feller, S. M. The leukaemic oncoproteins $\mathrm{Bcr}-\mathrm{Abl}$ and Tel-Abl (ETV6/Abl) have altered substrate preferences and activate similar intracellular signalling pathways. Oncogene 2000, 19, 1684-1690. (c) Danial, N. N.; Rothman, P. JAK-STAT signaling activated by Abl oncogenes. Oncogene 2000, 19, 2523-2531. (d) Kirchner, D.; Duyster, J.; Ottmann, O.; Schmid, R. M.; Bergmann, L.; Munzert, G. Mechanisms of Bcr-Abl mediated NF-kappaB/Rel activation. Exp. Hematol. 2003, 31, 504-511.

(4) Neshat, M. S.; Raitano, A. B.; Wang, H. G.; Reed, J. C.; Sawyers, C. L. The survival function of the Bcr-Abl oncogene is mediated by Bad-dependent and -independent pathways: roles for phosphatidylinositol 3-kinase and Raf. Mol. Cell. Biol. 2000, 20, 1179-1186.

(5) (a) Bedi, A.; Barber, J. P.; Bedi, G. C.; Bedi, A.; Barber, J. P.; Bedi, G. C.; El-Deiry, W. S.; Sidransky, D.; Vala, M. S.; Akhtar, A. J.; Hilton, J.; Jones, R. J. BCR-ABL-mediated inhibition of apoptosis with delay of G2/M transition after DNA damage: a mechanism of resistance to multiple anticancer agents. Blood 1995, 86, 1148-1158. (b) Bueno-Da-Silva, A. E.; Brumatti, G.; Russo, F. O.; Green, D. R.; Amarante-Mendes, G. P. Bcr-Abl-mediated resistance to apoptosis is independent of constant tyrosine-kinase activity. Cell Death Differ 2003, 10, 592-598.

(6) Deininger, M.; Buchdunger, E.; Druker, B. J. The development of imatinib as a therapeutcic agent for chronic myeloid leukemia. Blood 2005, 105, 2640-2653.

(7) de Bree, F.; Sorbera, L. A.; Fernàndez, R.; Castaner, J. Imitanib mesilate. Drugs Future 2001, 26, 545-552.

(8) Fang, G.; Kim, C. N.; Perkins, C. L.; Ramadevi, N.; Winton, E.; Wittmann, E.; Bhalia, K. B. CGP57148B (STI-571) induces differentiation and apoptosis and sensitizes bcr-abl-positive human leukemia cells to apoptosis due to antileukemic drugs. Blood 2000, $96,2246-2252$.

(9) Soverini, S.; Martinelli, G.; Rosti, G.; Bassi, S.; Amabile, M.; Poerio, A.; Giannini, B.; Trabacchi, E.; Castagnetti, F.; Testoni, N.; Luatti, S.; de Vivo, A.; Cilloni, D.; Izzo, B.; Fava, M.; Abruzzese, E.; Alberti, D.; Pane, F.; Saglio, G.; Baccarani, M. ABL mutations in late chronic phase chronic myeloid leukemia patients with up-front cytogenetic resistance to imatinib are associated with a greater likelihood of progression to blast crisis and shorter survival: a study by the GIMEMA Working Party on Chronic Myeloid Leukemia. $\underline{\text { J. Clin. }}$ Oncol. 2005, 23, 4100-4109.

(10) Thurston, D. E.; Bose, D. S. Synthesis of DNA-interactive pyrrolo[2,1-c][1,4]benzodiazepines. Chem. Rev. 1994, 94, 433-465.

(11) Tada-Oikawa, S.; Oikawa, S.; Kawanishi, M.; Yamada, M.; Kawanishi, S. Generation of hydrogen peroxide precedes loss of mitochondrial membrane potential during DNA alkylation-induced apoptosis. FEBS Lett. 1999, 442, 65-69.

(12) Rotas, G.; Natchkebia, K.; Natsvlishvili, N.; Kekelidze, M.; Kimbaris, A.; Varvounis, G.; Mikeladze, D. Action of a novel pyrrolo[1,2-c] $[1,3]$ benzodiazepine on the viability of Jurkat and neuronal/glial cells. Bioorg. Med. Chem. Lett. 2005, 15, 3220-3223.

(13) Artico, M.; Silvestri, R.; Pagnozzi, E.; Stefancich, G.; Massa, S.; Loi, A. G.; Putzolu, M.; Corrias, S.; Spiga, M. G.; La Colla, P. Pyrrolo[1,2- $b][1,2,5]$ benzothiadiazepines (PBTDs): a novel class of non-nucleoside reverse transcriptase inhibitors. Bioorg. Med. Chem. 1996, 4, 837-850.

(14) Chimenti, F.; Vomero, S.; Nacci, V.; Scalzo, M.; Giuliano, R.; Artico, M. Research on compounds with antiblastic activity. LVII. Anthramycin and related compounds. VI. Synthesis of pyrrolo[1,2- $b][1,2,5]-$ benzothiadiazepine derivatives. Farmaco 1974, 29, 589-597.

(15) Pictet, A.; Spengler, T. Formation of isoquinoline derivatives by the action of methylal on phenylethylamine, phenylalanine and tyrosine. Chem. Ber. 1911, 44, 2030-2036.

(16) (a) Stefancich, G.; Silvestri, R.; Pagnozzi, E.; Artico, M. Heterocycles with a benzothiadiazepine moiety. 2. Synthesis of 2-methyl-1,3,4, $14 b$-tetrahydro- $2 H$-pyrazino[2,1-d]pyrrolo[1,2-b]-[1,2,5]benzothiadiazepine 10,10-dioxide (tiaaptazepine). J. Heterocycl. Chem. 1994, 
31, 867-869. (b) Silvestri, R.; Artico, M.; Pagnozzi, E.; Stefancich, G.; Massa, S.; La Colla, P.; Loi, A. G.; Spiga, M. G.; Corrias, S.; Lichino, D. Synthesis and anti-HIV activity of 10,11-dihydropyrrolo[1,2-b][1,2,5]benzothiadiazepine-11-acetic acid 5,5-dioxide derivatives and related compounds. Farmaco 1996, 51, 425-430. (c)
Silvestri, R.; Artico, M.; Pagnozzi, E.; Stefancich, G. Heterocycles with a benzothiadiazepine moiety. 3. Synthesis of imidazo[5,1- $d]$ pyrrolo[1,2-b][1,2,5]benzothiadiazepine 9,9-dioxide. J. Heterocycl. Chem. 1994, 31, 1033-1036.

JM0602716 